\title{
Rapid and early determination of sex using trophoblast biopsy specimens and Y chromosome specific DNA probes
}

\author{
GILLES VERGNAUD， LILIANA KAPLAN，JEAN WEISSENBACH，YVES DUMEZ, \\ ROLAND BERGER, PIERRE TIOLLAIS, GEORGES GUELLAEN
}

\begin{abstract}
The feasibility of determining sex by analysing deoxyribonucleic acid (DNA) with two probes specific for $Y$ chromosomes was shown using DNA obtained from samples of blood from 30 non-related males and females of different ethnic origin. The DNA was spotted on nitrocellulose filters and hybridised with both a repetitive ( $P 1)$ and a unique (49f) sequence specific for the human $Y$ chromosome. A strong positive signal with both probes indicated the presence of male DNA. The sex of 12 fetuses was then similarly determined by molecular characterisation of DNA from trophoblast biopsy specimens. Chorionic samples were obtained in seven cases before termination of pregnancy in the first trimester and the aborted embryos subjected to karyotyping and sex chromatin analysis. In the five other cases samples were obtained from placentas obtained during caesarean section. Results of hybridisation were compared with those from cytogenic studies and actual sex at birth. The sex of all 12 fetuses was determined correctly by hybridisation.
\end{abstract}

Unité de Recombinaison et Expression Génétique, INSERM U-163, CNRS LA-271, Institut Pasteur, 75015 Paris, France

GILLES VERGNAUD, MS

JEAN WEISSENBACH, PHD

PIERRE TIOLLAIS, MD

GEORGES GUELLAEN, PHD

INSERM U-166, Maternité de Port-Royal, 75014 Paris

LILIANA KAPLAN, MD

Clinique Universitaire Port-Royal, Maternité de Port-Royal, 75014 Paris

YVES DUMEZ, MD

Laboratoire de Cytogénétique, UER d'Hématologie, Hôpital SaintLouis, 75475 Paris

ROLAND BERGER, MD

Correspondence to: $\mathrm{Mr} \mathrm{G}$ Vergnaud.
The use of both unique and repetitive sequences eliminates the possibility of diagnostic errors in females with $Y$ heterochromatin translocation and males with a small $Y$ chromosome not labelled with the sole repetitive probe. Prenatal determination of sex by this method takes only two days and is not subject to the technical difficulties inherent in the Southern blot technique.

\section{Introduction}

Early determination of the sex of a fetus is of great value for the prenatal diagnosis of some $\mathrm{X}$ linked recessive diseases. Until now this has been achieved by amniocentesis at the 18th week of pregnancy followed by either karyotyping, fluorescence analysis of culture cells, or, more rapidly, by hybridisation of $\mathrm{Y}$ specific repetitive deoxyribonucleic acid (DNA) probe to amniotic cells. ${ }^{1}$ Although this procedure is useful, it suffers from the risks associated with amniocentesis and is lengthy. Recently determination of fetal sex, either by direct karyotyping of chorionic villi ${ }^{2}$ or at the molecular level with $\mathrm{Y}$ specific DNA probes on trophoblast biopsy specimens obtained during the first trimester has been proposed as an improved alternative technique. The direct karyotyping of chorionic villi is sometimes hampered by a low number of mitoses, making analysis difficult. Gosden et al therefore developed a method for rapid prenatal determination of sex by analysing the DNA extracted from chorionic villi by restriction hydrolysis and Southern blotting followed by hybridisation with male satellite III DNA. ${ }^{3}$ This probe detects the male specific Hae III 3.4 kilobase (kb) band ${ }^{4}$ and numerous additional sequences present in both male and female DNA. Although elegant, this approach is limited by the technical difficulties inherent in the Southern blot procedure.

In the present study, using cloned unique and repetitive sequences specific for the $\mathrm{Y}$ chromosome, ${ }^{5-7}$ we found that analysis of DNA extracted from chorionic villi ${ }^{8}{ }^{9}$ could be done by dot blot. The assay took only two days and required less than $3 \mu \mathrm{g}$ of DNA, even for characterisation with the unique sequence. Moreover, the use of two independent male specific probes greatly improved the reliability of this method. 


\section{Patients and methods}

\section{TROPHOBLAST SAMPLES}

Trophoblast biopsy samples-As in previous studies placental biopsy was performed after six to eight weeks of pregnancy. ${ }^{8}$ Biopsies were carried out in five women who had given their informed consent before undergoing elective abortion. We used Dyonic biopsy forceps of $1.7 \mathrm{~mm}$ in diameter, introduced transcervically into the uterine cavity under real time ultrasonic guidance. ${ }^{210}$ Small tissue samples of trophoblast-that is, chorionic-villi were taken at the chorion frondosum side of the placenta. Tissues were washed in a sterile isotonic saline solution and examined immediately under a dissecting microscope. Any maternal decidual cells were carefully separated from the villi with brucels. Ten to $50 \mathrm{mg}$ of trophoblast villi were submitted for analysis of DNA. After abortion the products of conception were used for karyotyping or chromatin study.

Trophoblast villi-In another seven women small portions of trophoblast villi, similar to biopsy specimens, were dissected from the placental cotyledon once the placentas had been obtained during caesarean section.

\section{KARYOTYPE ANALYSIS AND CHROMATIN DETERMINATION OF SEX}

Fibroblasts from the five aborted embryos were allowed to grow in vitro, using routine procedures (RPMI 1640, fetal calf serum, and antibiotics in an atmosphere containing $5 \%$ carbon dioxide) Karyotypes were established by conventional techniques after 12-20 days' in vitro culture (second or third passage). Giemsa staining and $\mathrm{C}$ banding techniques were applied. Two to 10 mitoses were analysed. Sex chromatin was studied in interphasic cells from fibroblast cultures stained with toluidine blue. One hundred to 200 nucleuses were counted.

\section{PREPARATION AND ANALYSIS OF DNA}

Preparation of DNA from blood-Ten millilitres of blood was collected in $1 \mathrm{ml} 5 \%$ edetic acid (EDTA). (Blood samples were provided either by the Centre National de Transfusion Sanguine or by the Institut Pasteur Hospital.) Serum was eliminated by centrifugation. Red cells were lysed in $0.17 \mathrm{M}$ ammonium chloride and the leukocytes, collected by centrifugation, were lysed in $7 \mathrm{M}$ urea, $2 \%$ sodium dodecyl sulphate, $0.2 \mathrm{M}$ sodium chloride, $10 \mathrm{mM}$ trometamol (TRIS) $\mathrm{pH} 8$, and $1 \mathrm{mM}$ edetic acid, extracted twice with phenol:chloroform $(\mathrm{v} / \mathrm{v})$, twice with chloroform, and precipitated with ethanol. The precipitate was collected by spooling and dissolved in $10 \mathrm{mM}$ trometamol pH 8 and $1 \mathrm{mM}$ edetic acid containing ribonuclease $\mathrm{A}(50 \mu \mathrm{g} / \mathrm{ml})$. The solution was incubated at $37^{\circ} \mathrm{C}$ for one hour, then supplemented with $1 \%$ sodium dodecyl sulphate, $10 \mathrm{mM}$ edetic acid, and $100 \mu \mathrm{g} / \mathrm{ml}$ proteinase $\mathrm{K}$ final concentrations, and then incubated for a further two hours. The solution was extracted once with chloroform, dialysed in $10 \mathrm{mM}$ trometamol $\mathrm{pH} 8$ and $1 \mathrm{mM}$ edetic acid overnight, and precipitated with ethanol once again. The final precipitate was dissolved in $200 \mu \mathrm{l}$ of $10 \mathrm{mM}$ trometamol $\mathrm{pH} 8$ and $1 \mathrm{mM}$ edetic acid.

Preparation of DNA from trophoblast samples-The samples were incubated in $0.4 \mathrm{ml}$ of $10 \mathrm{mM}$ sodium chloride, $10 \mathrm{mM}$ trometamol $\mathrm{pH} 8,10 \mathrm{mM}$ edetic acid, $0.5 \%$ sodium dodecyl sulphate, and $100 \mu \mathrm{g} / \mathrm{ml}$ proteinase $\mathrm{K}$ in an Eppendorf plastic tube at $37^{\circ} \mathrm{C}$ and shaken for three hours, then extracted, once with phenol:chloroform $(\mathrm{v} / \mathrm{v})$, once with chloroform, precipitated with ethanol, and dissolved in $100 \mu \mathrm{l}$ of $10 \mathrm{mM}$ trometamol pH 8 and $1 \mathrm{mM}$ edetic acid.

Analysis of DNA-The DNA was exposed to sound waves, denatured in $0.4 \mathrm{M}$ sodium hydroxide and $1 \mathrm{M}$ sodium chloride at $4^{\circ} \mathrm{C}$ for half an hour, and neutralised just before filtration on nitrocellulose filter in $1.5 \mathrm{M}$ trometamol and sodium chloride $\mathrm{pH} 7$. Before filtration the nitrocellulose filter was washed in $6 \times$ SSC solution $(1 \times$ SSC $=$ $0.15 \mathrm{~mol} / 1$ sodium chloride, $0.015 \mathrm{~mol} / 1$ sodium citrate). After filtration it was dried at $80^{\circ} \mathrm{C}$ for two hours; prehybridised in $6 \times \mathrm{SSC}$ solution containing $1 \times$ Denhardt's solution $(1 \times$ Denhardt's solution $=$ $0.02 \mathrm{mg} / 100 \mathrm{ml}$ Ficoll, $0.02 \mathrm{mg} / 100 \mathrm{ml}$ polyvinyl pyrrolidone, 0.02 $\mathrm{mg} / 100 \mathrm{ml}$ bovine serum albumin) for one hour at $68^{\circ} \mathrm{C}$; hybridised overnight with the radioactive probe $\left(10^{6}\right.$ disintegrations per minute $(\mathrm{dpm})$ for the repetitive probe $\left(10^{8} \mathrm{dpm} / \mu \mathrm{g}\right)$ and $20 \times 10^{6} \mathrm{dpm}$ for the unique sequence at the same specific activity) in $1 \times$ Denhardt's solution, $2 \times \mathrm{SSC}$ solution, $0.5 \%$ sodium dodecyl sulphate, $2 \mathrm{mM}$ edetic acid, and $25 \mathrm{mM}$ sodium dihydrogen phosphate at $68^{\circ} \mathrm{C}$; washed twice at $68^{\circ} \mathrm{C}$ in $0.1 \times \mathrm{SSC}$ solution, $0.1 \%$ sodium dodecyl sulphate for one hour; and exposed overnight at $-70^{\circ} \mathrm{C}$. At least $1 \mu \mathrm{g}$ or $0 \cdot 1 \mu \mathrm{g}$ of DNA had to be spotted to produce an interpretable signal with the unique and the repetitive probe respectively.

\section{Results}

We used two different male specific probes. The repetitive probe (P1), obtained as described elsewhere, ${ }^{7}$ is a 400 base pair (bp) subfragment of the $2.1 \mathrm{~kb} Y$ specific repetitive sequence. ${ }^{4}$ The unique sequence (49f) is a $2 \cdot 8 \mathrm{~kb}$ fragment isolated by Bishop et al. ${ }^{56}$ The specificity of these probes for male DNA was assessed on genomic blots of male and female DNA (fig 1). Under stringent conditions both probes are highly specific for male DNA with the absence of any band on the genomic blot of female DNA.
P1

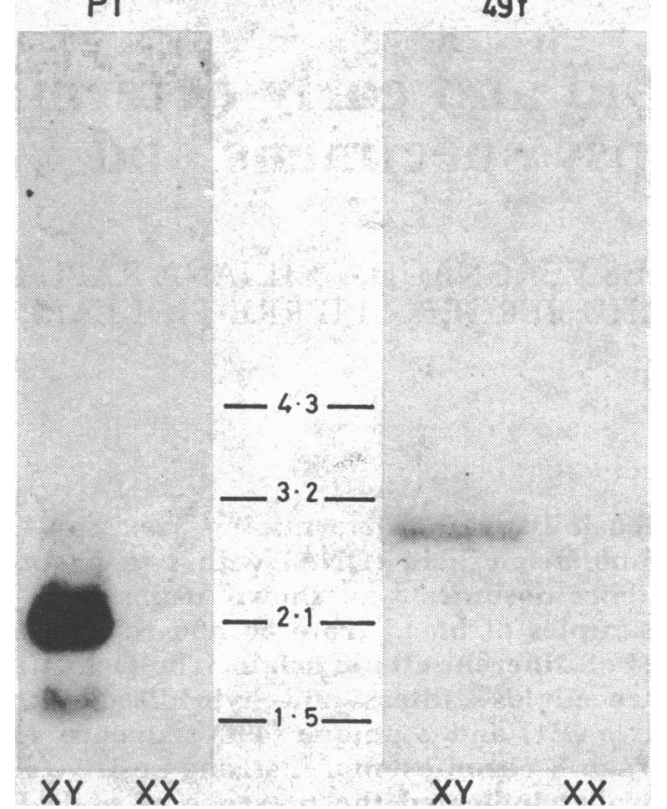

FIG 1-Hybridisation of $\mathrm{Y}$ chromosome specific probes to male and female genomic blots. Twenty micrograms of male (XY) or female (XX) DNA were hydrolysed with Hae III or Eco RI, run on a $0.8 \%$ agarose gel, and transferred on nitrocellulose filter. The Hae III blot was hybridised with $1 \times 10^{6} \mathrm{dpm}$ of ${ }^{32} \mathrm{P}$ labelled P1 repetitive probe. The Eco R1 blot was hybridised with $20 \times 10^{6}$ $\mathrm{dpm}$ of ${ }^{32} \mathrm{P}$ labelled $49 \mathrm{f}$ unique sequence probe at the same specific activity. Both filters were washed under stringent conditions $\left(0 \cdot 1 \times \mathrm{SSC}\right.$ solution at $\left.68^{\circ} \mathrm{C}\right)$. The size of the markers is indicated in $\mathrm{kb}$ pair unit.

We further investigated the specificity of these probes in dot blot experiments. Figure 2 shows hybridisation of the two probes to known amounts of spotted male and female DNA. A strong positive signal was observed with male DNA, using both the repetitive and the unique probes, with only a slight background on the spots corresponding to female DNA. Figure 2 also shows the result of hybridisation on dot blots of the Hae III $3.4 \mathrm{~kb}$ fragment, corresponding to the male specific band identified by satellite III DNA. ${ }^{3}$ Our results showed the higher specificity (at least 10-fold) of the subfragment of the $2 \cdot 1 \mathrm{~kb}$ Y specific sequence for male DNA as compared with the $3.4 \mathrm{~kb}$ fragment already used on dot blot analysis of amniotic cells. ${ }^{1}$ As the background may vary with the amount of DNA bound to the filter, and to estimate this amount, hybridisation of an identical set of dot blot was systematically done with the Alu probe, which is uniformly present in male and female genome. ${ }^{11}$ The use of new $\mathrm{Y}$ specific probes led us to show the universality of this system. For this purpose, blind determination of sex from samples of DNA from different ethnic groups was tried. Using 30 blood samples from African, European, and Asiatic non-related males and females we predicted the correct sex in all the cases analysed. 
Having shown the feasibility of determination of sex by analysis of DNA, we proceeded to study Y specific sequences in the 12 samples of chorionic tissue. The samples weighed roughly $30 \mathrm{mg}$, and the yield of DNA was roughly $15 \mathrm{~kg}$ as estimated by Alu measurement.

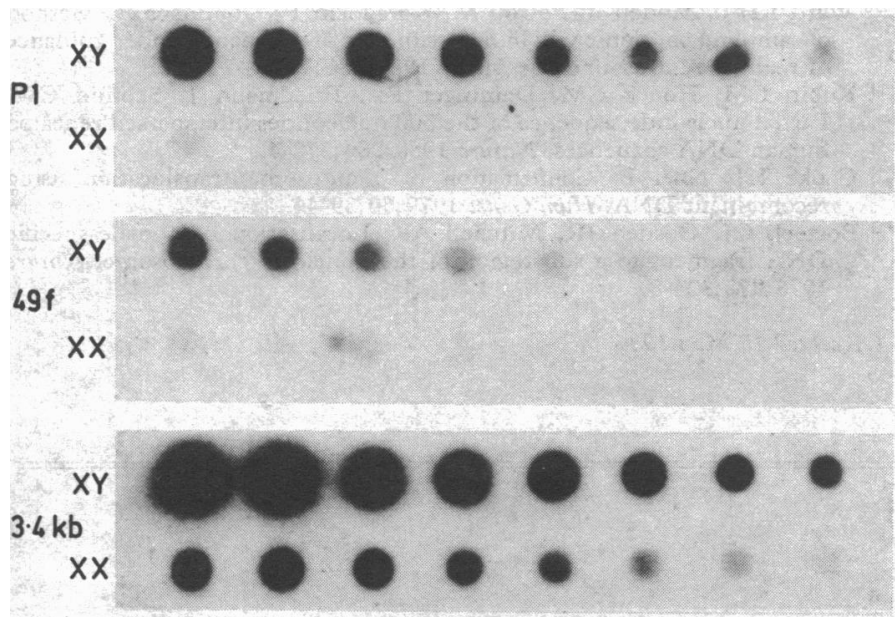

FIG 2-Hybridisation of increasing concentrations of male and female DNA with $\mathrm{Y}$ chromosome specific probes. A twofold serial dilution of eight spots of male (XY) and female (XX) DNA was done on nitrocellulose filters and hybridised with either $1 \times 10^{6} \mathrm{dpm}$ of the P1 or the $3.4 \mathrm{~kb}$ probes or $20 \times 10^{6} \mathrm{dpm}$ of the $49 \mathrm{f}$ probe. Blots were washed under stringent conditions $\left(0 \cdot 1 \times \mathrm{SSC}\right.$ solution at $\left.68^{\circ} \mathrm{C}\right)$

The table and figure 3 show the results of the hybridisation with Alu probe and the two $\mathrm{Y}$ specific sequences of the 12, spotted DNA samples. In each case comparison with either the results of cytogenetic studies or actual sex of the babies at birth by caesarean section showed that we had used sufficiently large amounts of DNA to identify fetal sex.

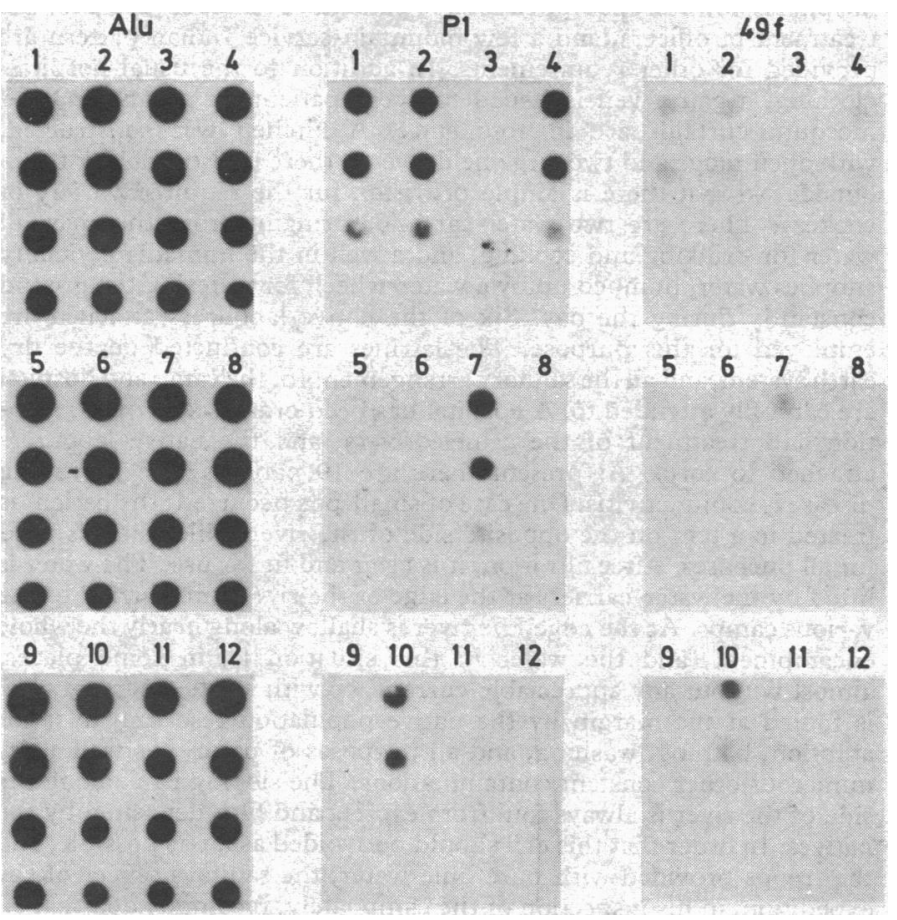

FIG 3-Hybridisation of chorionic DNA to Alu and Y chromosome specific probes. DNA extracted from 12 samples of chorionic tissue was spotted in a fourfold serial dilution of four spots. Three identical filters were hybridised with $1 \times 10^{6} \mathrm{dpm}$ of the Alu and the P1 probes and $20 \times 10^{6} \mathrm{dpm}$ of the $49 \mathrm{f}$ probe. Blots were washed under stringent conditions $(0.1 \times \mathrm{SSC}$ solution at $68^{\circ} \mathrm{C}$ )

\section{Discussion}

We have described an improved technique for detecting the $\mathrm{Y}$ chromosome in samples of trophoblast tissue obtained during the first trimester of pregnancy. The method of Gosden et al necessitates the hydrolysis of the chorionic DNA to detect a male specific pattern by hybridisation analysis ${ }^{3}$ because of the lack of male specificity of satellite III DNA. We have overcome

Results of determination of sex in 12 pregnancies

\begin{tabular}{|c|c|c|c|c|c|c|}
\hline $\begin{array}{l}\text { Case } \\
\text { No }\end{array}$ & $\begin{array}{l}\text { Age of } \\
\text { mother } \\
\text { (years) }\end{array}$ & $\begin{array}{l}\text { Type of } \\
\text { sample }\end{array}$ & $\begin{array}{l}\text { Observation } \\
\text { of sex } \\
\text { at birth }\end{array}$ & $\underset{\text { karyotype }}{\text { Fetal }}$ & $\underset{\text { chromatin }}{\text { Fetal }}$ & $\begin{array}{c}\text { Results of } \\
\text { DNA } \\
\text { hybridisation }\end{array}$ \\
\hline $\begin{array}{r}1 \\
2 \\
3 \\
4 \\
5 \\
6 \\
7 \\
8 \\
9 \\
10 \\
11 \\
12\end{array}$ & $\begin{array}{l}27 \\
34 \\
28 \\
33 \\
38 \\
35 \\
34 \\
32 \\
16 \\
32 \\
24 \\
31\end{array}$ & $\begin{array}{l}\mathbf{C S}^{*} \\
\mathbf{C B} \\
\mathbf{C S}^{*} \\
\mathbf{C S}^{*} \\
\mathbf{C S}^{*} \\
\mathbf{C S}^{*} \\
\mathbf{C B}^{*} \\
\mathbf{C S}^{*} \\
\mathbf{C B}^{*} \\
\mathbf{C S}^{*} \\
\mathbf{C B}^{*} \\
\mathbf{C B}\end{array}$ & $\begin{array}{l}\mathrm{M} \\
\mathrm{F} \\
\mathrm{M} \\
\mathrm{F} \\
\mathrm{F} \\
\mathrm{F} \\
\mathrm{M}\end{array}$ & $\begin{array}{l}\mathrm{F} \\
\mathrm{F}\end{array}$ & F & $\begin{array}{l}M \\
M \\
F \\
M \\
F \\
F \\
M \\
\text { F } \\
F \\
M \\
F \\
F\end{array}$ \\
\hline
\end{tabular}

*Chorionic villi obtained after caesarean section.

tChorion biopsy specimen obtained before termination of pregnancy during first trimester.

this drawback by using cloned probes (either repetitive or unique) highly specific for the $\mathrm{Y}$ chromosome and with a low background. As figure 3 shows, this permitted the determination of fetal sex, from analysis of chorionic DNA, by a simple dot blot hybridisation procedure that can be routinely used for medical analysis. The use of the unique sequence appears to be justified by the following points. Firstly, although the repetitive probe P1 permitted a rapid (less than two hours of exposure), sensitive, and correct determination of sex in most of the cases, we observed hybridisation of this probe to DNA from a woman bearing a $\mathrm{Y}$ translocation whereas the unique sequence $49 \mathrm{f}$ remained undetected (data not shown). Of particular relevance to our study are the results obtained by Cooke and Noël, showing the presence of male specific bands $(3.4 \mathrm{~kb}$ and $2 \cdot 1 \mathrm{~kb})$ in six women bearing a $\mathrm{Y}$ translocation among 12000 male and female karyotypes analysed. ${ }^{22}$ Secondly, the male repetitive sequences are known to be located on the distal part of the long arm of the $\mathrm{Y}$ chromosome, ${ }^{13}$ which is highly heteromorphic, whereas the unique probe $49 \mathrm{f}$ has been mapped in the euchromatic part of the long arm of the $Y$ chromosome and is still present in the genome of normal males bearing a small $\mathrm{Y}$ chromosome (results not shown). The DNA of these subjects might therefore not react with the P1 probe, but they will be detected with the unique sequence 49f. Finally, we established that both $\mathrm{Y}$ specific sequences are present in human males independently of the ethnic origins so far tested.

The use of two types of $Y$ specific DNA probe appears to be a better control than the use of one repetitive sequence. For the time being, no probe located on the short arm of the $\mathrm{Y}$ chromosome has been found to be suitable for determination of sex on dot blots, but this is being investigated. A series of unique sequences for sex determination would constitute the best probe, permitting the replacement of the P1 probe. As specific markers, or polymorphisms, associated with $\mathrm{X}$ linked conditions are lacking the determination of sex by dot blot with trophoblast biopsy specimens remains the most sensitive diagnostic technique in these $\mathrm{X}$ linked diseases.

We thank Dr A M Courroucé, Pr P Meyer, and Dr B Noël for providing us with various types of blood samples; Dr F Chisari for his helpful comments and advice; and C Johnsson for technical help. GV is a student from the Ecole Nationale Superieure des Techniques Avancées. This study was supported by INSERM, CNRS, and the Faculté de Médecine Lariboisière-Saint Louis (University of Paris VII). 


\section{References}

${ }^{1}$ Lau YF, Huang JC, Dozy AM, Kan YW. Rapid screening test for antenatal sex determination. Lancet $1984 ; \mathrm{i}: 14-6$.

2 Simoni G, Brambati B, Danesino C, et al. Efficient direct chromosome analyses and enzyme determinations from chorionic villi samples in the first trimester of pregnancy. Hum Genet 1983;63:349-57.

${ }^{3}$ Gosden JR, Mitchell AR, Gosden CM, Rodeck CH, Morsman JM. Direct vision chorion biopsy and chromosome specific DNA probes for determination of foetal sex in first trimester prenatal diagnosis. Lancet 1982 ;ii:1416-9.

4 Cooke H. Repeated sequence specific to human males. Nature 1976;262: 182-6.

5 Bishop C, Guellaën G, Geldwerth D, Voss R, Fellous M, Weissenbach J. Single copy sequences specific for the human $\mathrm{Y}$ chromosome. Nature 1983;303:831-2.

${ }^{6}$ Bishop C, Guellaën G, Geldwerth D, Fellous M, Weissenbach J. Extensive sequence homologies between $\mathrm{Y}$ and other human chromosomes. f Mol Biol 1984;173:403-17.

7 Bernheim A, Metezeau P, Guellaën G, Fellous M, Goldberg ME, Berger R. Direct hybridization of sorted human chromosomes: localisation of the Y chromosome on flow karyotype. Proc Natl Acad Sci USA 1983;80:7571-5.

${ }^{8}$ Kaplan L, Dumez Y, Goossens M. A method for fetal tissue sampling by chorion biopsy: a new approach to first trimester prenatal detection of abnormal genes. International Research Communications System Medical Science 1983;11:85-6.

${ }^{9}$ Goossens M, Dumez Y, Kaplan L, et al. Prenatal diagnosis of sickle cell anemia in the first trimester of pregnancy. N Englf Med 1983;309:831-3.

10 Ward RHT, Modell B, Petrou M, Karagozlu F, Douratsos E. Method of sampling chorionic villi in first trimester of pregnancy under guidance of real time ultrasound. Br Med F 1983;286:1542-4.

1 Rubin CM, Houck CM, Deininger PL, Friedmann J, Schmid CW. Partial nucleotide sequence of the 300 nucleotides interspersed repeated human DNA sequences. Nature 1980;284:372-4.

12 Cooke HJ, Noël B. Confirmation of $\mathrm{Y} /$ autosome translocation using recombinant DNA. Hum Genet 1979;50:39-44.

${ }^{13}$ Bostock CJ, Gosden JR, Mitchell AR. Localisation of a male-specific DNA fragment to a sub-region of the human $\mathrm{Y}$ chromosome. Nature 1978;272:324-8.

(Accepted 16 May 1984)

\section{ONE HUNDRED YEARS AGO}

The inglorious struggle of the Dewsbury guardians against the vaccination laws has at length been terminated by the election of public vaccinators for the Thornhill and Mirfield Districts, whose appointments have now been sanctioned by the Local Government Board. The history of this contest is not devoid of interest. It was on November 23rd, 1883, when a delay of four months had already happened, that the guardians resolved that it was unnecessary to appoint public vaccinators, and asked the Local Government Board to interpret the law to them. In a communication dated December 11th, the Central Board expounded the law at length; and, later on (after an adjournment of the question for another three months), their inspector attended a meeting of the guardians, explained their position, and foreshadowed the action of the authorities at Whitehall. On April 10th of the present year, the guardians rescinded their directions to the vaccination-officer to prosecute defaulters, and resolved that no further steps be taken to fill up the vacant appointments pending the reply of the Local Government Board to this resolution. It should be observed that, at this meeting, one of the majority stated that "they took shelter in a little diplomacy," and admitted that they were doing this to avoid the law. A fortnight later, the Local Government Board threatened that, unless the appointments were made at the following meeting (May 9th), they would instruct their solicitors to move in the matter. At this particular meeting, however, the question was again shelved by a resolution to advertise for applications to be made on forms which contained conditions which no medical man would dream of accepting. At length, the Local Government Board, after another delay, placed the matter in the hands of their solicitors, who informed the guardians accordingly. The result of the legal proceedings which followed is too well known to be recorded here; and the action of the Court of Queen's Bench, in requiring the immediate appointment of the necessary officers, was generally anticipated. The only question now remaining to be disposed of is that of the payment of costs, which is still under consideration. Some doubt is expressed whether, after all, the Local Government Board will insist upon the necessary costs being paid by the recalcitrant guardians who openly defied their mandates; but, if the costs be not demanded, it seems to us that the whole proceedings will amount to little less than a farce. There are other boards of guardians who, while not openly defying the vaccination-laws, practically refuse to administer them; and upon these any leniency of the Central Board towards the Dewsbury guardians will have a particularly damaging effect. (British Medical fournal 1884.)

Assouan is the first principal military station occupied by British troops on the Nile. The general health of the troops is good, and the men are in good spirits. To relieve the monotony of camp-life, games of cricket, rounders, etc, are played in the afternoon; and in some of the regiments, open-air concerts are held every second night from 8 to 9.15. The tents used are the Indian pattern Sepoy and Lascar palls; there is no overcrowding, and every tent is provided with a large chattie filter. Each battalion and corps has a proportion of native labourers, varying in number from 14 to 20 ; they are employed for carrying water and attending to the general cleanliness of the surface. There is likewise a fatigue-party told off daily. Bathing parades are held every evening. The men are marched down to the river by companies, and, where the water is deep, arrangements are made by ropes and poles to prevent accidents; provision is made for ablution and washing. The field-rations are liberal and of good quality; fresh beef, vegetables, and bread have been issued daily, except for a few days, and the cooking is varied as much as possible. The hospital was established on the arrival of the 1st Battalion Sussex Regiment on July 9th; the railway-station was cleansed, and taken for the purpose. It contains three wards, for 25 patients; this accommodation has since been supplemented by 22 Indian pattern British privates' tents. The hospital is now fully equipped for 200 patients; a tent is set apart for the treatment of officers, and a few mountain-service Indian pattern are provided for other requirements. In addition to the usual hospitalclothing, a gauze veil is issued to every patient on admission, and mosquito-curtains are in abundance. A kitchen was constructed, with open range and two large field-ovens; there is also a field-kitchen outside, so that there is ample provision for the required variety of cookery. There are two water-carts for bringing from the river all water for drinking and cooking, and a well in the immediate vicinity supplies water, pumped up by a water-wheel, for watering the ground constantly during the day. Six of the native labourers attached are employed for this purpose. The latrines are conducted on the dry earth system, and all the sanitary arrangements of the camp and hospital are carefully attended to. A hospital has been organised for the reception and treatment of the camel-drivers, and the native labourers attached to corps. At present there are 19 patients; the prevailing disease is conjunctivitis. One case of small-pox occurred; the patient is treated in a tent on the opposite side of the river. Nile water is used for all purposes. After filtration, it is clear and fit for use. The water is lifted by the water-carriers at the edge of the river, and carried to the various camps. At the edge, the river is shallow along nearly the whole encampment, and the water in this situation is, in some places, almost without any appreciable current, or with a reflex current, and is fouled at the margin by the native population resorting to it for ablution, bathing, washing, and all purposes of nature, as well as by numerous other constant contaminations. The sloping bank along the side of the river is always foul from excreta and filth deposited by the natives. In order that this evil should be avoided as far as possible, and the troops provided with pure Nile water, the sanitary officer of the expedition, in his inspection of the camp lately, recommended that all water from the river should be taken, by means of trestles and planks, or temporary platforms, at a depth of at least four feet, and at a distance of eight or twelve feet from the margin, according to depth. It is expected that this purer water-supply, which has an important bearing on the health of the troops, will be attended with the most beneficial results. (British Medical fournal 1884;ii:930.) 